\title{
Close Range Photogrammetry and Constructive Characterization of Masonry Gothic Vaults
}

\author{
Fotogrametría de Rango Cercano y la caracterización constructiva de bóvedas góticas de obra de \\ fábrica
}

Josep Lluis i Ginovart (Main Author)

Universitat Rovira i Virgili, ETSA Reus Campus Bellissens;

Josep.lluis@urv.cat

Josep Ma Toldrà

Universitat Rovira i Virgili, ETSA Reus Campus Bellissens

jmtoldra@gmail.com

\author{
Agustí Costa (Corresponding Author) \\ Universitat Rovira i Virgili, ETSA Reus Campus Bellissens \\ agusti.costa@urv.cat \\ C/Universitat 1, 43204 Reus, Spain / Telf: +34 977779913
}

\section{Sergio Coll}

Universitat Rovira i Virgili, ETSA Reus Campus Bellissens

sergio.coll@estudiants.urv.cat

Código: 0211

Fecha de Recepción: 01.01.2014.

Fecha de Aceptación: 01.04.2014.

\begin{abstract}
The representation of the plan of the roof in heritage buildings often raises the problem of direct measurement, since the points are not accessible. We currently have a wide range of indirect measurement techniques that solve this problem, and enable data to be captured on a massive scale with high levels of accuracy. The article discusses the use of Close Range Photogrammetry for the constructive analysis of gothic vaults in Tortosa Cathedral. The methodology and results of the campaign are explained below, which used technological resources that are available to any professional. The computerized processing of the 3D model generated makes possible to identify and analyze the geometric anomalies in the masonry vaults. Thereby it is obtained an unparalleled basis that enables us to undertake a detailed study of the vaulting, which was previously impossible. The geometrical deviation patterns can be related with the historical data available about the construction process of the gothic apse, fulfilling the lack of information from direct sources of some periods.
\end{abstract}

\section{Resumen}

La representación del plano de la cubierta en edificios patrimoniales a menudo plantea el problema de la medida directa, puesto que los puntos no son accesibles. Actualmente disponemos de un amplio abanico de técnicas de medida indirectas que solucionan este problema y permiten la captura masiva de datos con gran precisión. El artículo presenta la utilización de la Close Range Photogrammetry para análisis constructivo de las bóvedas góticas de la Catedral de Tortosa. Se exponen la metodología y resultados de la campaña realizada utilizando medios tecnológicos al alcance de cualquier profesional. A partir del tratamiento informático del modelo 3D generado, es posible determinar y analizar las anomalías geométricas de las bóvedas de fábrica. Así, se obtiene una base documental sin precedentes que permite el estudio detallado del conjunto abovedado, antes imposible de realizar. Es posible relacionar los patrones de las desviaciones geométricas con los datos históricos disponibles sobre el proceso de construcción del ábside gótico, completando la falta de información de las fuentes directas en algunos periodos.

Keywords: Photogrammetry; Close Range Photogrammetry; Masonry Vaults.

\section{INTRODUCTION}

The preservation of built heritage is generating nowadays an important scientific activity from multiple disciplines all over the world (Moropoulou, 2013), (Morán, 2012), (Roca, 2010). The detailed assessment of masonry vaults has always involved the problem of accessibility. Direct surveying requires a complex and expensive scaffolding system, and the data collection takes a great deal of time. Modern indirect measurement techniques such as digital photogrammetry and Terrestrial Laser Scanner (TLS) enable automated massive data capture in three dimensions (Yastikli, 2007) which makes the process considerably quicker. Both techniques are commonly used nowadays in the assessment of historical buildings (Macareno, 2007), (Armesto, 2010), (Grussenmeyer, 2008), sometimes combined, sometimes as standalone techniques (El-Omari, 2008), (Al-Kheder, 2009). Perhaps photogrammetric techniques have a better cost-precision ratio (Riveiro, 2010) and they are therefore used more widely (Arias, 2006).
The use of photogrammetry enables a fast and low-cost methodology for the accurate recording of complex geometries (Yilmaz, 2008). In recent years its use has grown significantly in a wide range of disciplines, as topography (Abd Elbasit, 2009), archaeology (Campana, 2007), (Barazzetti, 2011) or even biology (Growcott 2012) and accident reconstruction ( $\mathrm{Du}, 2009$ ) between others. Of course, it has been also used in the digital recording and the assessment of heritage constructions (Sharaf et al., 2009), (Fuji, 2009), (Ordoñez, 2010). In this context, the assessment of cathedrals is a major challenge due to the complexity of their architecture. Despite that, some authors have successfully applied these methodologies (Fassi, 2011; Martínez 2013).

In this paper, it is discussed the use of Close-Range Photogrammetry (CRP) for the assessment of Gothic vaults from a historical standpoint. The performance of an accurate geometric layout of the structure reveals formal differences between the vaults, which are at first sight all the same. This enables the analysis of the possible deformations and the evaluation their impact on the 
preservation of the monument based on the construction history.

Thus, this method is used to assess the vaults in the apse of the gothic Cathedral of Tortosa, which was built between (1383-1441), (Almuni, 2007). The results of the methodology enable a comparative study from different disciplines, using data obtained from direct documentary sources from this period, such as the Libros de Fábrica (LI.o.), which are preserved in the Tortosa Chapter Archive (ATCO).

\section{Theoretical framework}

Massive data capture techniques are commonly used to obtain planimetric bases for the geometric and structural analysis of masonry buildings (Armesto, 2009) (Schueremans, 2009). The generally complex and irregular shapes of these buildings mean that the use of these techniques is essential. The data must be treated to obtain useful information and they often require post-processing that simplifies their geometry (Lourenço, 2001).

Photogrammetry is a passive remote sensing technique which requires a short duration of field work without any contact with the object. It provides a great deal of automated spatial information, using image correlation algorithms that identify the common points in photographs of the same object (Karara, 1989). Close Range Photogrammetry (CRP) refers to the capture of objects with a size that does not exceed $100 \mathrm{~m}$, where the camera is in a position close to the object (Cooper, 2001).

The photogrammetric Model orientation theory (Arias, 2007) states that geometric reconstruction in $3 D$ is mathematically solved in two steps: a) Internal orientation: reconstruction of the bundle perspective geometry in the camera system of each photograph. b) External orientation: the position of each bundle in relation to a coordinate system is determined, and also its relationship with the reference bundle. This enables the calculation of the position and orientation of the perspective centre of the camera. The identification of a minimum number of common points between the images is needed.

Restitution consists of the identification and intersection of the equivalent rays in the photographs to find their position in space. The position of a point in space is defined by a Cartesian coordinate system in three dimensions. The origin, scale and orientation can be defined arbitrarily, and conversion between different coordinate systems is often necessary. Coordinate transformations are divided into 3 parts: translation, rotation and scaling (see Arias (2005) for more information). Today, these operations are performed by specific automated programs.

The work operations or phases are therefore (Riveiro, 2013), (Núñez, 2012): a) Data capture: photographs (at least two per object) and topographical measurements to reference the objects. b) Obtaining measurements and shapes: confirmation of the positions of the objects based on the location of the corresponding points in the images. c) Application of transformations: construction of the geometry using specific software. The post-processing phase starts after the three-dimensional model has been obtained. This will provide the data required for the studies to be carried out.

\section{CASE STUDY. THE APSE OF TORTOSA CATHEDRAL (1383-1441)}

\section{Adjustment of measures}

Tortosa Cathedral has an apse with a double ambulatory (1383-1441), with a construction chronology that has been precisely determined using the church construction accounts (see Almuni (2007) V2). At the beginning of the project, the master established the unit of measurement, asking for a cana for the new cathedral (1347) (Almuni, 1991).

As a result, the basic standard for the measurements in the Llibres d'Obra (church construction accounts) (ACTO) is the cana. The cana is equivalent to 8 palms, and the palm to 12 fingers. The Tortosa cana is defined in Book IX, Rubric 15.5 of the Consuetudines Dertosae (1272) (AHCTE cod.53, fol.256r), and in the copy dating from 1346, Llibre de les Costums Generals feutes de la insigne ciutat de Tortosa (FBMPM, fol.100r), which is when work began on the Gothic cathedral. A comparison of the documents standardizing the Tortosa cana with the one used in Barcelona (24-VII1593) shows that the Tortosa cana used in the cathedral measures $1,858 \mathrm{~cm}$ and the palm measures $23.23 \mathrm{~cm}$.

\section{Chronology and theoretical model}

After the work on the Gothic building had begun, it came to a standstill due to the Black Death (1347) and the War of the two Peters (1356-1369). Construction resumed in the late fourteenth century. An initial phase of building construction from a chronological point of view can be determined, with the construction of a ring of nine radial chapels around the Romanesque cathedral, which remained in use (Lluís, 2013). They have a square floor plan, with ribbed vaults, and were built sequentially, from the Gospel side to the Epistle, between (1383-1424). The theoretical cross-section of the keystones was topped at 45 palms $(1,045.35 \mathrm{~cm})$ (Lluís, 2009)

The second phase saw the construction of nine vaulted ceilings in the ambulatory (1424-1435). Two are square, and seven are trapezoidal, with a theoretical deployment of the cross-section of the keystone 72 palms $(1672.56 \mathrm{~cm})$ high. Unlike the radial chapels, the vaults were built symmetrically, from the mouth of the apse towards the choir, in a west-east direction.

Finally, the roof of the presbytery (1435-1441) was topped with a keystone 10 palms in diameter $(232.3 \mathrm{~cm})$, which had to be placed exactly 100 palms $(2323 \mathrm{~cm}$ ) high (Lluís, 2011). The cross-section of the radial chapels $(1383-1424)$ has a ratio of $9 / 5$ ( 9 units high by 5 at the base) while in the ambulatory (1424-1435) and in the presbytery (1435-1441) it has a ratio of $9 / 6$. 
The main studies of Gothic vaults refer to the typological arrangement of the roof of the apse of Tortosa cathedral, with its double ambulatory (Willis, 1842), (Viollet-le-duc, 1854-1868), (Viollet-le-duc, 1996), (Ungewitter, 1890-1892), (Babcock, 1893), (Drum, 1901). In typological terms, the radial chapels are connected visually, with the traditional separation wall being replaced by a pillar on the ambulatory. The release of the wall between the chapels had been tentatively attempted at Santa María de la Aurora in Manresa (1328), with a cross-section ad triangulum of $8 / 7$. This wall was completely released in Tortosa in around 1377 , establishing a lower cross-section ratio of $9 / 5$. The evolution of the apse can therefore be seen in terms of an empirical practice. This structural issue appeared years later in the debate over the Cathedral of Milan (1392) (Yarza, 1982), (Valentini, 1990)

\section{The construction process and geometric variations.}

The reference for the study of the vaults is the theoretical $9 / 5$ deployment model of the vaults in the radial chapels at $10.45 \mathrm{~m}$; it $9 / 6$ in the ambulatory at $16.73 \mathrm{~m}$, and in the presbytery it is $23.23 \mathrm{~m}$. It is possible to establish the precise sequence in the construction process of the vaults. There are well-documented examples, such as the trapezoidal sector of the ambulatory, located opposite the Chapel of San Vicente. In this area measuring $20.03 \mathrm{~m} 2$, the scaffolding was placed on 24 July, 1433, it was shored up on 31 July, the vault was constructed between 1 and 5 August and it was taken down on 27 August. This final operation completed the structural process, which took 35 days.

The filling of this vault was built between 2 and 13 September, as well as the inner wall and the tiling of the exterior finish. This was done in two layers, and this operation completed the masonry work. A ribbed vault in the ambulatory was built and covered in just eight weeks [6, 2: 584-587]. After the scaffolding was removed, the masonry arch began to push against the buttresses along a specific line of thrust. The buttresses inevitably yielded slightly, and the light of the arch increased by a small amount. In order to accommodate this movement, the arch tends to move apart and its geometry is recomposed (Huerta, 2004).

However, this was not the only cause of the deviations from the theoretical cross-section. The anomalies may be caused by: a) Implementation and application techniques using different auxiliary resources. This depends on geometric questions, the height of the centering and the tension of the vaults. It also depends on the execution of the work and the setting of the mortar joints, although in this case they are very thin. Finally, a descent and translation of the centering used to build the vault is also possible. b) Settling of the vaults after decentering. There is usually some subsidence and displacement of the buttresses immediately after unshoring. This may sometimes lead to a descent of the keystone, due to the consistency of the perpends in the joint of the sternotomy of the vault. Over time, there may also be some settling in the masonry, with a possible impact on the conditions around the abutment.
The base of the centering of the vaults in the radial chapels is not constant, as it varies substantially between 5.94 and $8.29 \mathrm{~m}$. In the ambulatory, the lines of the imprints of the nine vaults are located at a constant height of $13.12 \mathrm{~m}$. The same applies to the presbytery, where it is possible to identify the eleven masonry carvings at $17.09 \mathrm{~m}$, which subsequently covered the cavities in the scaffolding.

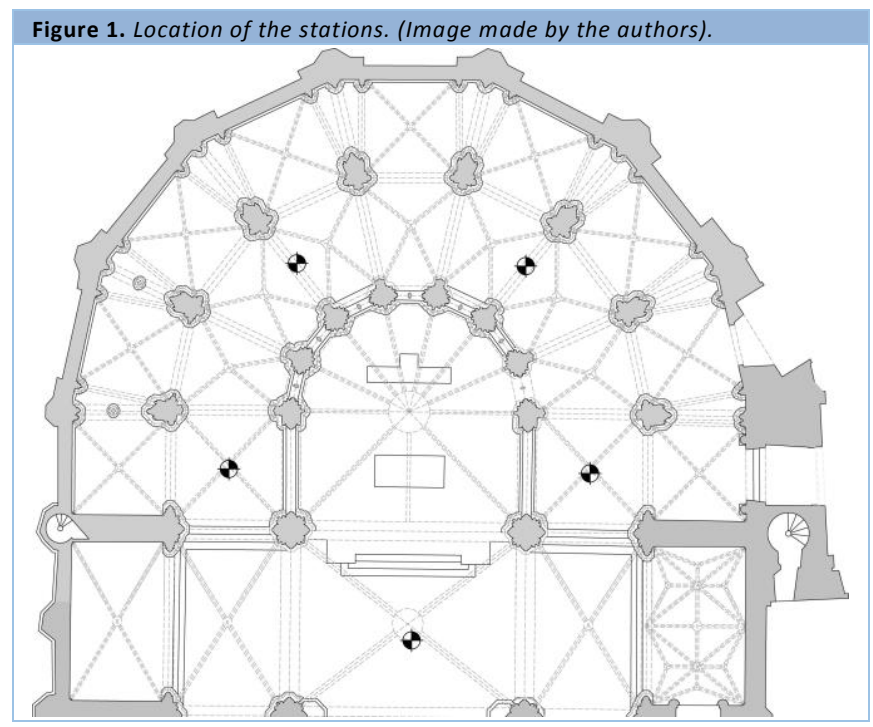

METHODOLOGY

\section{Background}

The first computerized topography of Tortosa Cathedral was performed between (1995-2000), for the Sancta Maria Dertosae Master Plan (Lluís, 2000). The data capture for the survey was conducted using direct measurements, referenced to polygonal points fixed by a total station. The numerical data were stored using CAD applications, providing a survey with an error of approximately $3 \mathrm{~cm}$.

The model is sufficiently accurate for the ground floor of the cathedral, but is of little use in ascertaining the plan of the top of the vaults. To that end, it is carried out a campaign for the three-dimensional modelling of the cathedral's heading ceiling in the summer of 2012.

\section{Data acquisition}

The 3D model is constructed by combining the data obtained with a total station, Topcon Imaging Station 203, with a precision of $0.2 \mathrm{~mm} / 1 \mathrm{~mm} \pm(5 \mathrm{~mm})$, and those from the thorough photography of the vaults with a Nikon D7000+ Tokina 12-24 calibrated camera, using the extreme focal lengths of the zoom: $12 \mathrm{~mm}$ and $24 \mathrm{~mm}$.

Due to its size and shape, it is impossible to capture the entire vaulted ceiling with one shot. It is therefore necessary to capture partial images of the vaults and identify common points for the outward orientation based on a Cartesian system, according to the mathematical principles of photogrammetry (Riveiro, 2013) 
The topography of the apse was performed using 221 points, with five positioning stations - four in the ambulatory area and one above the axis of the main nave (Figure 1). Singular points of the carved reliefs in the keystones of the vault were used as a reference to record them in a single system of coordinates. Thus, it is obtained a survey with discrepancies of less than $10 \mathrm{~mm}$ at in the positions of the reference points captured from different locations.

At least 2 photographs were taken for each vault, with a very high overlapping percentage, and 7 for mapping the presbytery, as well as some supplementary shots of special areas. Usual parameters for capturing images have been taken into account (Arias, 2007) in the lighting and overlap. However, the changing internal light conditions and the different exposure of the surfaces obliged to pre-process the images in order to equalize the texture.

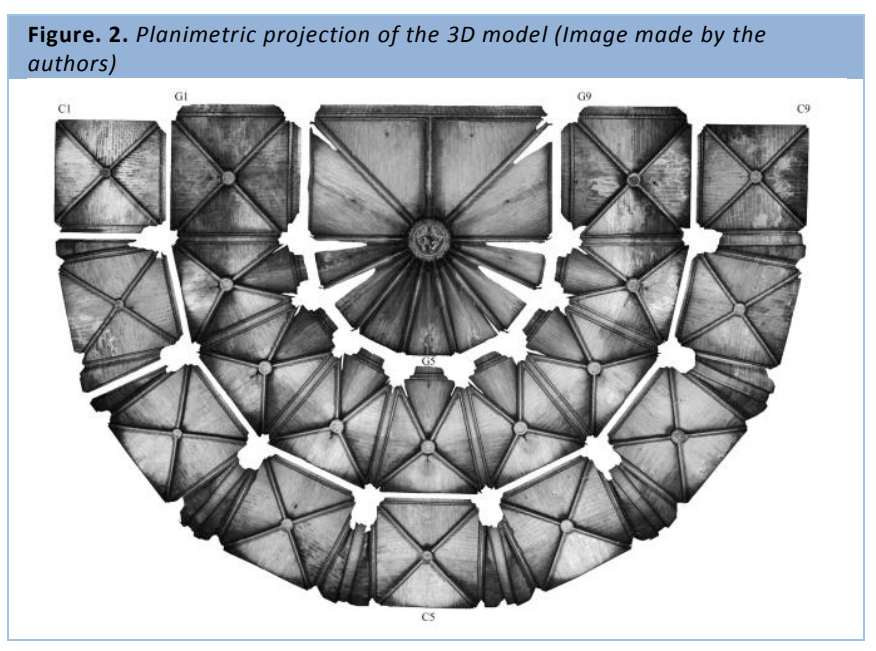

3D model generation

3D modelling is generated by surfaces from stereo pairs of photographs oriented by means of topographic points, called control points. It is used the Image Master Topcon software to generate the surfaces, which consist of TIN (triangulated irregular network) triangular meshes. These incorporate the real textures of the masonry by mapping with the same stereo pairs of photographs. The proposed mesh pass is $30 \mathrm{~mm}$ (i.e. the triangles of the meshes have sides of $30 \mathrm{~mm}$ under optimum conditions).

The result is a 3D model with metric scale, which incorporates the textures of the assessed vaults (Figure 2). Metric scale orthophotos, contour models and sections of the masonry vaults were generated from the virtual model. The treatment of the results and their possible discrepancies will be analyzed from a statistical standpoint. Data discrimination and parameterization of the results is necessary to do so (Rosin, 1996), (Rosin, 2001).

This operation provides an approach to the geometrical properties of the apse with a precision that was previously impossible through traditional techniques. Using the $3 D$ model obtained, it is undertaken a thorough reading of the vaults in the Gothic cloister, identifying the formal deviations by the parameterization of their geometry.

This operation provides an approach to the geometrical properties of the apse with a precision that was previously impossible through traditional techniques. Using the $3 \mathrm{D}$ model obtained, it is undertaken a thorough reading of the vaults in the Gothic cloister, identifying the formal deviations by the parameterization of their geometry.

\section{RESULTS. GEOMETRIC PARAMETERS}

The methodology allows the vaults to be simulated in three dimensions, so that the measurement by a system $(x, y, z)$, is carried directly by means of the 3D model. Furthermore, the methodology provides also a planimetric twodimensional topographic representation with orthogonal projections of the dome, and contours (Bechman, 1981). A nomenclature is established for each vault (Figure 3 ), and for the significant points of their geometry (Figure 4), distinguishing between Chapels (C) and Ambulatory (G). As regards the geometric points, two cutting planes are defined (SI and SII). It is identified four characteristic points in each one: a) Height of the keystone. b) Height of the vault where it meets the keystone. c) Height of the vault where it meets: the perimeter wall (in SI) and the transverse arch in contact with the following vault (in SII). d) Height of the vault where it meets: the formeret towards the ambulatory that opens in the chapel (in SI) and the transverse arch in contact with the previous vault (in SII).

Having determined the characteristic points, numerical values are listed to undertake a comparative study of the deviations in each vault. Although there are apparently no significant differences between those of the same type, their topography is not uniform and it has been possible to quantify the deviations.

\section{Chapels}

The height of the keystones $(\mathrm{Ha})$ in the chapels differs by up to $39.1 \mathrm{~cm}$, with the keystone located at the greatest height in C2 $(10.285 \mathrm{~m})$ and at the lowest height in C8 $(9.894 \mathrm{~m})$. A progressive loss of height from $\mathrm{C} 1$ to $\mathrm{C} 9$ is also apparent, with the first 3 keystones being the highest. The next two chapels are of a similar height ( $C 2$ and $C 3$, with a difference that does not reach $7 \mathrm{~cm}$ ), while the last 4 tend to be lower, with $\mathrm{C7}$ being the highest $(10.068 \mathrm{~m})$. The height of the severy in the keystone $(\mathrm{Hb})$ follows the same pattern as that described for the keystone, with small variations.

If we compare the heights of $\mathrm{Hc}$ and $\mathrm{Hd}$ in $\mathrm{SI}, \mathrm{Hc}$ is always located higher than $\mathrm{Hd}$. The dispersion in the former is $\mathbf{2 5 . 2}$ $\mathrm{cm}$ (from $10.589 \mathrm{~m}$ in C4 to $10.337 \mathrm{~m}$ in $\mathrm{C} 3$ ) and in the latter it is $17.8 \mathrm{~cm}$ (from $10.307 \mathrm{~m}$ in $\mathrm{C} 8$ to $10.129 \mathrm{~m}$ in C3). The height of the first three vaults is lower than the others. C2 is the highest of the three, with a height of $10.441 \mathrm{~m}$ in $\mathrm{Hc}$ and $10.277 \mathrm{~m}$ in $\mathrm{Hd}$, and $\mathrm{C} 3$ is the lowest in the entire group. There is a greater dispersion of values in the case of $\mathrm{S}$.II, and $\mathrm{Hc}>\mathrm{Hd}$ is not always true. Likewise, the first three chapels also tend to have the lowest values. The heights range between $17.3 \mathrm{~cm}$ for $\mathrm{Hc}$ (C9 $10.272 \mathrm{~m}$ and C4 10.445 
$\mathrm{m}$ ) and $18.6 \mathrm{~cm}$ for $\mathrm{Hd}$ (C8 $10.414 \mathrm{~m}$ and $\mathrm{C} 110.228 \mathrm{~m}$ ) (Figure 4).

\section{Ambulatory}

The height of the keystones in the vaults ( $\mathrm{Ha}$ ) of the ambulatory follows a different pattern. Their height ranges from $23.2 \mathrm{~cm}$ (G1 $16.152 \mathrm{~m}$ and G2 $15.919 \mathrm{~m}$ ), with the ends being the highest. The height tends to decrease, and is regained at the centre. As in the chapels, the height of the severy in the keystone $(\mathrm{Hb})$ follows the same pattern.

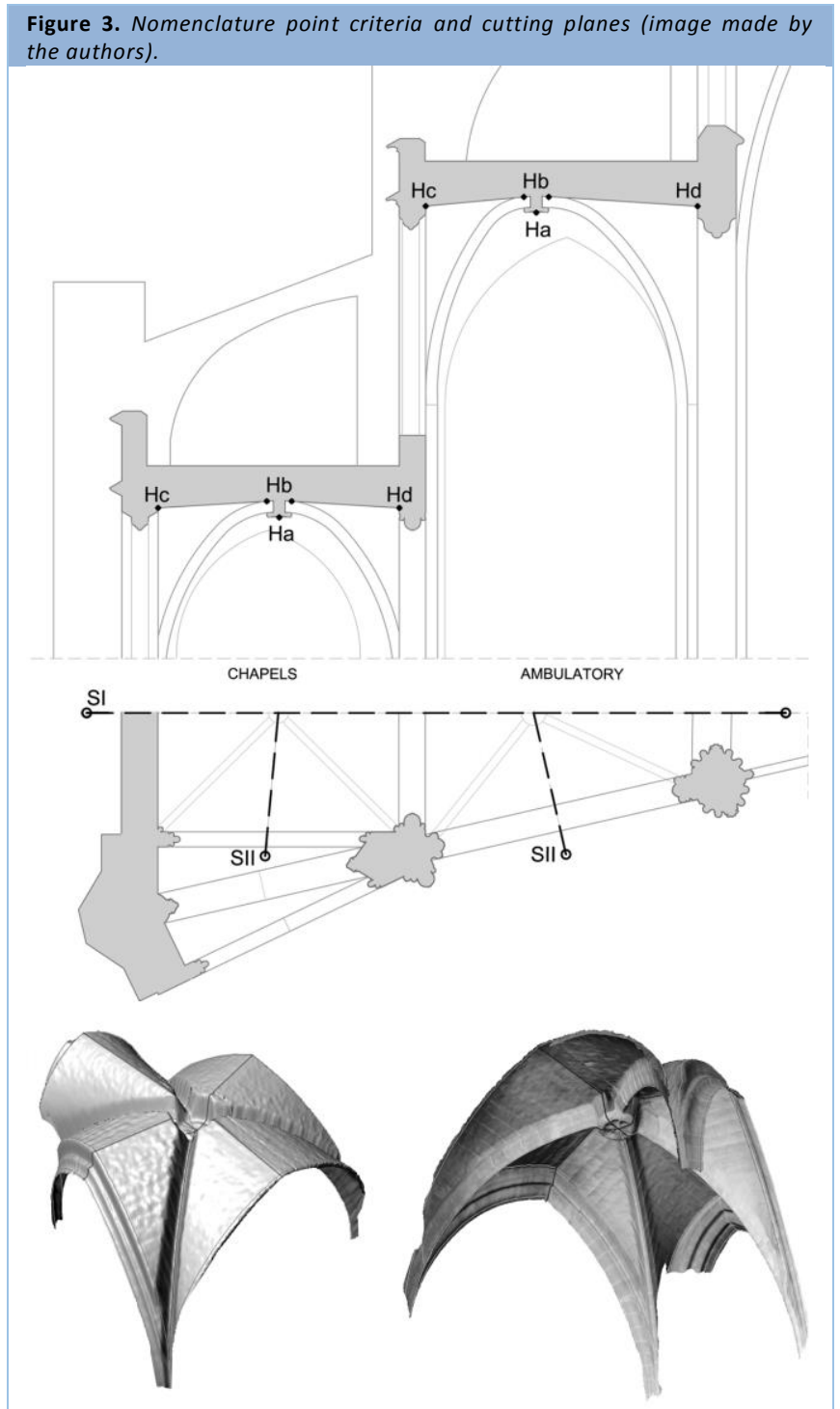

Figure 4. Heights of the vaults in the chapels (graphic made by the authors).

\section{SI.Chapels}

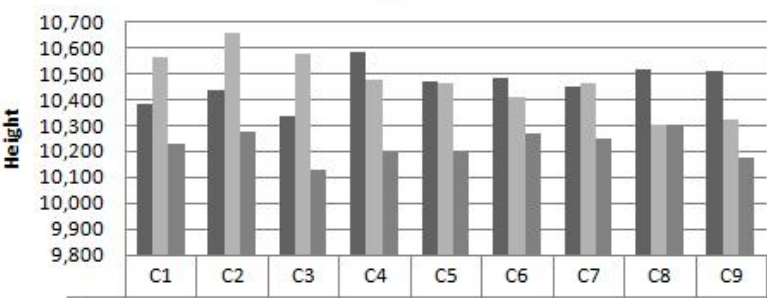

\begin{tabular}{l|l|l|l|l|l|l|l|l|l|l} 
ㅂc & 10,381 & 10,441 & 10,337 & 10,589 & 10,470 & 10,487 & 10,454 & 10,518 & 10,513
\end{tabular} \begin{tabular}{l|l|l|l|l|l|l|l|l|l|l} 
wb & 10,568 & 10,657 & 10,577 & 10,477 & 10,468 & 10,413 & 10,468 & 10,302 & 10,325
\end{tabular}

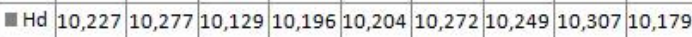

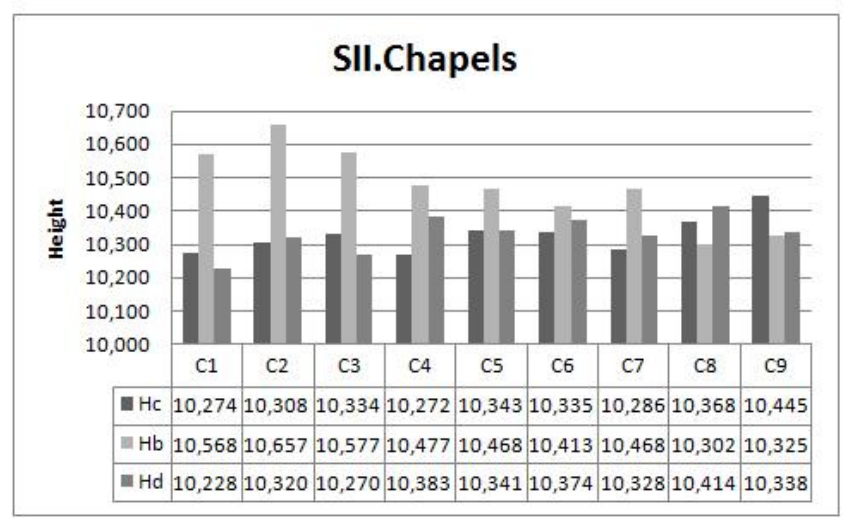

Figure 5. Heights of the vaults in the ambulatory (graphics made by the authors).

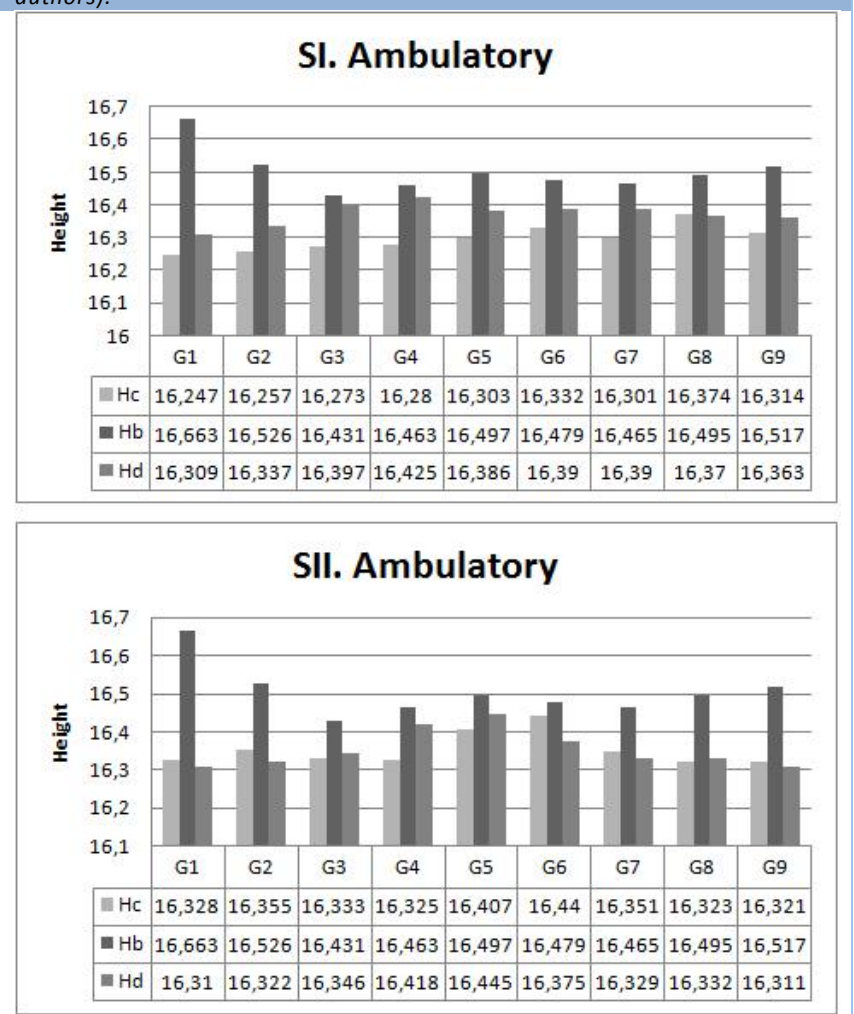




\section{DISCUSSION}

For $\mathrm{Hc}$ and $\mathrm{Hd}$ in S.I, except for $\mathrm{G} 8, \mathrm{Hc}$ is lower than $\mathrm{Hd}$, in contrast to the vaults of the chapels. The dispersion in the former is $12.4 \mathrm{~cm}$ ( $16.247 \mathrm{~m}$ in $\mathrm{G} 1$ to $116.371 \mathrm{~m}$ in G8) and in the second it is $29 \mathrm{~cm}$ (16.309 in G1 to $16.28 \mathrm{~m}$ in G4).

In the case of S.II the heights range from $11.9 \mathrm{~cm}$ for $\mathrm{Hc}$ (16.44 $\mathrm{m}$ in $\mathrm{G} 6$ to $16.321 \mathrm{~m}$ in $\mathrm{G} 9$ ) and $13.5 \mathrm{~cm}$ for $\mathrm{Hd}$ (16.31 in $\mathrm{G} 1$ to $16.445 \mathrm{~m}$ in $\mathrm{G5}$ ), with the three central vaults (G4, G5 and $G 6$ ) being the tallest. Except in some cases, the difference in height between the two points is very small (Figure 5).

Comparative analysis based on the sources available and the results obtained in the three-dimensional model, lets to establish a relationships between the masonry executed and the historical chronology of construction (Figure 6).

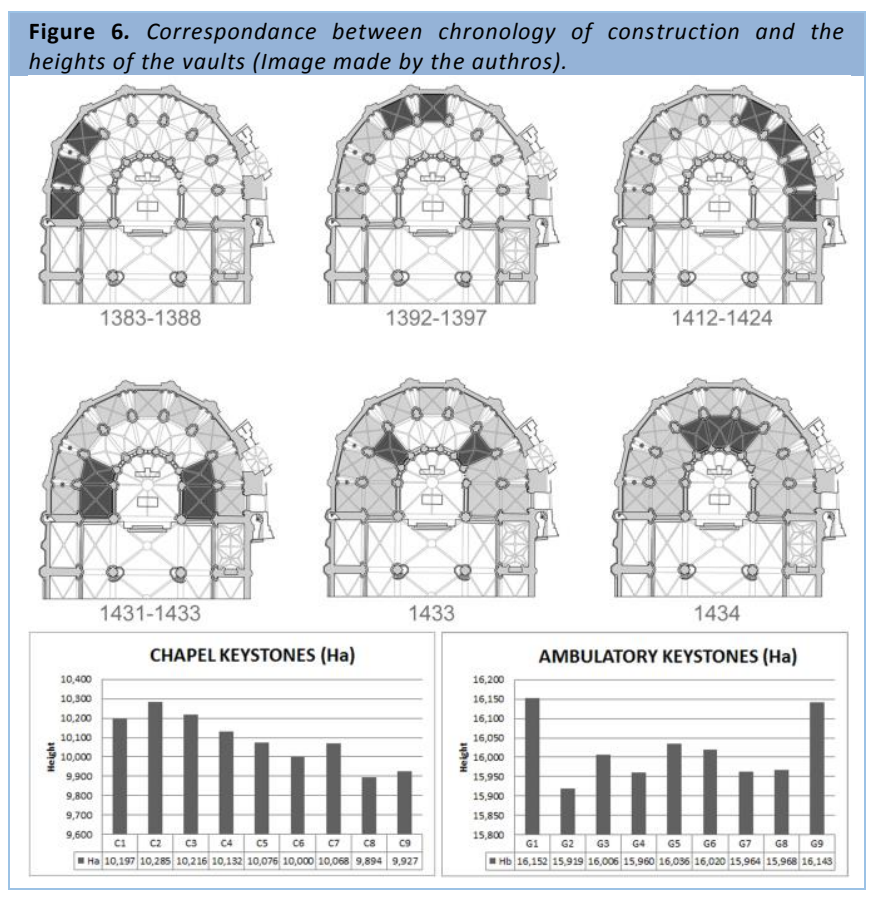

\section{The vaults in the radial chapels (1383-1424)}

The participation of four masters in the construction of the radial chapels could be determined through the sources (Lluís, 2002). They made various adjustments to the carvings and mouldings in the masonry. Three periods of construction in the building of the radial chapels are identified. The first (1377-1383), with the initial trials of the model, in chapels C1, C2 and C3 (San Pedro, San Pablo and San Vicente). Afterwards, between (1387-1397) came the consolidation and adaptation of the model, with the construction of the next two chapels. The third, from (14121424), saw the systematic construction of the remaining four chapels. The construction took place as a belt from the chapel of the gospel (C1) to the chapel of the epistle (C9). Based on an analysis of the relationship obtained between the geometric points, there is a clear correspondence between the succession of constructive moments and the geometric variations.

The first three vaults ( $\mathrm{C} 1$ to $\mathrm{C} 3$ ) have the keystone at the highest point, and have a pattern that is clearly different from the rest. C4 breaks with the previous pattern, and there is a successive stabilization of the pattern, with the keystone at a lower height and similar relationships between the other points. The pattern changes significantly once again in the last two chapels (C8 and C9)

\section{The vaults of the ambulatory (1432-1434).}

After the closure of the chapels surrounding the Romanesque cathedral, the main pillar was constructed in May 1428 as ancillary feature, and the demolition of the Romanesque cathedral's chancel began in August (Almuni, 2004). The vaults in the ambulatory were constructed between (1432-1434). The construction strategy for the ambulatory is different from the one used in the chapels, which were roofed consecutively. Roofing of the ambulatory thus began symmetrically, with the chapels of the gospel and epistle. Those with a square plan were done first, followed by the seven with trapezoidal plans. In structural terms, the formerets and Perpignan-style arches and transepts of the ambulatory are executed on the same impost, with the vault topped at a theoretical cross-section of 72 palms $(16.73 \mathrm{~cm})$.

The tables show a pattern in the variation of heights that is the same as in the constructive process of the vaults shown, and this is especially evident in SII. The end vaults thus have a larger difference in height between the keystone and the other points, while there is a progressive loss of height in vaults G2-G8 and G3-G7, which then increases once again.

\section{The theoretical model vs. the constructed model}

As stated in point 2.3, many factors can change the geometry of the masonry constructed. The theoretical model of the cross-section is implemented according to proportional rules based on the layout of the floor. Although we do not have the original planimetry, by knowing these rules and the metric used we can deduce its measurements with precision. The comparison between the theoretical model and the virtual 3D reconstruction may therefore provide some relevant information about the alterations suffered by the masonry.

Metric analysis of the 3D model reveals that the vault keystones in chapels tend to be higher than its theoretical height, while in the ambulatory most of them are lower. For setting some values, in the case of chapels, the most extreme distortions in absolute values are $21 \mathrm{~cm}$ in $\mathrm{C} 2(\mathrm{~h}=10.66 \mathrm{~cm})$, and $15 \mathrm{~cm}$ in $\mathrm{C} 8$ $(\mathrm{h}=10.30 \mathrm{~cm})$. In the ambulatory, the variations identified range from $7 \mathrm{~cm}$ in $\mathrm{G} 1(\mathrm{~h}=16.66 \mathrm{~cm})$ to $30 \mathrm{~cm}$ in $\mathrm{G} 2(\mathrm{~h}=16.43$ $\mathrm{cm}$ ). Finally, the keystone is located at $23.18 \mathrm{~cm}$, which is only 5 $\mathrm{cm}$ lower than its theoretical height.

In relative terms, the deviations range between $0.2 \%$ and $1.8 \%$ compared to the theoretical plan. Although some absolute values may be high, the geometric variations suffered by the masonry do not therefore exceed $4 \%$ in any case. If we take into account that part of this deformation probably took place 
during the process of staking, construction and decentering, the structure can be said to have barely experienced any significant geometric alterations over the centuries.

\section{CONCLUSIONS}

The methodology used enables the geometrical distortions of arches and vaults to be determined by means of a relatively simple data capture. This provides the precise ichonographia of the roof plane, and identifies the anomalies compared to a theoretical section. The technique used, involving common technological resources, is available to any professional, and focused on the orthogonal representation of the higher plane. In this case, the method is ineffective for the vertical walls, due to the amount of shadows caused by the architectural configuration.

The 3D model obtained allows the parameterization of the geometry of the vaults, accurately locating the development of arches and severy. The analysis of the guidelines of the vaults is based on the geometric points that define their deployment. This allowed us to determine some structural details, such as the constructive nuances of the ambulatory and radiating chapels.

It is difficult to distinguish between the deformations caused by the execution and centering of the vaults (type a), and the settling that may have occurred after the centering (type b). However, the geometry after the deformation process is perfectly defined in the 3D model, and can be seen to have changed substantially compared what was initially anticipated (Barlow, 1846).

Meanwhile, the layout in the old style of the vaulted ceiling was well-known, in which the keystone of the vault is placed higher than the formerets and transverse arches, while these did not have the keystone at the same height (Lluís, 2009). The topography obtained shows that there is also some degree of canting in the external quarter of the vault. In construction terms, this is important, since it exerts a passive pressure so that the entire ribbed vaulting acts on the pillar of the ambulatory in this manner. There is a similar subtle effect in the ambulatory, in the room with the vault located above the presbytery. The keystones in the toral arches are not at the same height, as the one in the presbytery is higher. This means that the thrust line (Heyman, 2001) tended towards the inside of the masonry after the presbytery had been closed.

It is thus possible to identify geometric patterns that relate the different vaults of the apse with the execution process, which can be deduced from the historical sources and the study of the masonry. It was also possible to observe a significant variation in the geometric layout of vaults $\mathrm{C} 8$ and c9 compared to the others. This could be related to a change in mastership that is not mentioned in the Libres d'Obra (LLo.).

So, the results of the methodology discussed here provide new data compatible with the information from direct sources from the church construction accounts (LI.o.). Using the geometric variations, it is possible to identify and clarify the various masters that worked on the masonry between (1377-1434). Additionally, the 3D model provides the basis for the structural analysis of the masonry and allows for some confirmations based on the theory of arches (Huerta, 2004).

The methodology presented here is therefore a powerful tool for the analysis of masonry vaults. As well as providing some conclusions about the balance of the vaults, it also provides data on the construction history, complementing other analyses that can be performed on historic buildings.

Future research would focus on the use of these methodologies in other cases, exploring new applications in the assessment of ancient buildings. The interaction with other disciplines will play a key role in that sense.

In the particular case of Tortosa Cathedral, the 3D model enables a wide range of possibilities. Never before has it been possible to assess the geometry of the vaults with such accuracy. Thus, further research will deepen in the assessment of this medieval construction.

Finally, the Close Range Photogrammetry technique has presented some limitations because of the architectural configuration and the lighting conditions. The implementation of other technologies, as the ones based on laser devices, would improve the data capture workflow.

\section{ABBREVIATIONS}

TLS: Terrestrial Laser Scanner

CRP: Close Range Photogrammetry

Ll.o.: Construction Accounts - Llibres d'Obra

ATCo: Tortosa Chapter Archive - Arxiu Capitular de Tortosa

Abd Elbasit, M. A. M., Anyoji, H., Yasuda, H., Yamamoto, S., (2009). Potential of low cost closerange photogrammetry system in soil microtopography quantification. Hydrological Processes, 23 (10), 1408-1417.

Al-kheder, S., Al-shawabkeh, Y., Haala, N., (2009). Developing a documentation system for desertpalaces in Jordan using 3D laser scanning and digital photogrammetry. Journal of Archaeological Science, 36 (2), 537-546.

Almuni, V., (1991). L'Obra de la Seu de Tortosa (1345-1441). Tortosa: Cooperativa Gràfica Dertosense.

Almuni, V., (2004). La catedral románica de Tortosa. Aproximació documental a la seva història. Recerca, 8, 211-250.

Almuni, V., (2007). La catedral de Tortosa als segles del gòtic. 2 Vols. Barcelona: Fundació Noguera. Collecció Estudis.

Arias, P., Herraez, J., Lorenzo, H., Ordóñez, C., (2005). Control of structural problems in cultural heritage monuments using close-range photogrammetry and computer methods, Computers \& Structures 83 (21-22), 17541766. 
Arias, P., Ordóñez, C., Lorenzo, H., Herraez, J., (2006). Methods for documenting historical agro-industrial buildings: a comparative study and a simple photogrammetric method. Journal of Cultural Heritage, 7(4), 350-354.

Arias, P., Armesto, J., Di-Capua, D., González-Drigo, R., Lorenzo, H., Pérez Gracia, V., (2007). Digital photogrammetry, GPR and computational analysis of structural damages in a mediaeval bridge, Engineering Failure Analysis, 14 (8) 1444-1457.

Arias, P., Caamaño, J.C., Lorenzo, H., Armesto, J., (2007). 3D modelling and section properties of ancient irregular timber structures by means of digital photogrammetry. Computer-Aided Civil and Infrastructure Engineering 22 (8), 597-611.

Armesto, J., Lubowiecka, I., Ordóñez, C., Ria, F.I., (2009). FEM modeling of structures based on close range digital photogrammetry. Automation in Construction, 18 (5), 559-569.

Armesto, J., Roca-Pardiñas, J., Lorenzo, H., Arias, P., (2010). Modelling masonry arches shape using terrestrial laser scanning data and nonparametric methods. Engineering Structures, 32 (2), 607-615.

Babcock, C., (1893). Vaults, by Professor Charles Babcok. Boston: Cornell University.

Barazzetti, L., Binda, L., Scaioni, M., Taranto, P., (2011). Photogrammetric survey of complex geometries with low-cost software: application to the "G1" temple in Myson. Vietnam. Journal of Cultural Heritage, 12 (3), 253-262.

Barlow, W. H., (1846). On the existence of the line of equal horizontal thrust in arches, and the mode of determining it by geometrical construction. Minutes and Proceedings of the Institution of Civil Engineers. 5, 162-182.

Bechman, R., (1981). Les racines des cathédrales. Paris: Éditions Payot\&Rivages.

Campana, S., Remondino, F., (2007). Fast and detailed digital documentation of archaeological excavations and heritage artifacts. 35th Computer Applications and Quantitative Methods in Archaeology Conference, Berlin, Germany. 36-42.

Cooper, M., Robson, S., (2001). Theory of Close Range Photogrammetry. In: Atkinson K.B. (Ed.), Close Range Photogrammetry and Machine Vision (9-51). Caithness, Scotland: Whittles Publishing.

El-Omari, S., Moselhi, O., (2008). Integrating 3D laser scanning and photogrammetry for progress measurement of construction work. Automation in Construction, 18 (1), 1-9.

Drum, (1901), Handbuch der Architektur. Dritter Teil: Die Hochbau konstruktionen. 2 Band. Raumbegrenzende Konstruktionen. Heft 3,b. Stuutgart. Arnold Bergsträsser.

Du, X., Jin, X., Zhang, X., Shen, J., Hou, X., (2009). Geometry features measurement of traffic accident for reconstruction based on close-range photogrammetry. Advances in Engineering Software, 40(7), 497-505.
Fassi, F., Achille, C., Fregonese, L., (2011). Surveying and modelling the main spire of Milan Cathedral using multiple data sources. Photogrammetric Record, 26 (136), 462-487.

Fujii, Y., Fodde, E., Watanabe, K., Murakami, K.., (2009). Digital photogrammetry for the documentation of structural damage in earthen archaeological sites: the case of Ajina Tepa. Tajikistan. Engineering Geology, 105 (1-2), 124133.

Growcott, A., Sirguey, P., Dawson, S.M., (2012). Development and Assessment of a Digital Stereo Photogrammetric System to Measure Cetaceans at Sea. Photogrammetric Engineering \& Remote Sensing, 78 (3), 237-246.

Grussenmeyer, P., Landes, T., Voegtle, T., Ringle, K.., (2008). Comparison methods of terrestrial laser scanning, photogrammetry and tacheometry data for recording of cultural heritage buildings. International Archives of Photogrammetry, Remote Sensing and Spatial Information Sciences, 37 (B5), 213-218.

Heyman, J., (2001). The Science of Structural Engineering. (Spanish translation: La ciencia de las estructuras. Madrid: Instituto Juan de Herrera). London: Imperial College Press.

Huerta, S., (2004). Arcos, bóvedas y cúpulas. Geometría y equilibrio en el cálculo tradicional de estructuras de fábrica. Madrid: Instituto Juan de Herrera.

Karara, H. M., (1989). Non Topographic Photogrammetry. ASPRS, Falls Church, Virginia.

Lluis, J., Llorca, A., (2000). Pla Director Sancta Maria Dertosae. Tortosa: Bisbat de Tortosa. Departament Cultura Generalitat de Catalunya.

Lluis J., (2002). Geometría y diseño medieval en la catedral de Tortosa: la catedral no construida. PhD Thesis. Escuela Superior de Arquitectura. UIC [Tesis en español]

Lluis, J., (2009). Evolución constructiva de los pilares de una girola gótica. El concepto de homogeneidad del material versus resistencia. Sexto Congreso Nacional Historia de la Construcción. Valencia.

Lluis, J., Almuni V., (2011). La clave de la clau. El cierre constructivo del presbiterio gótico. Actas del Séptimo Congreso Nacional Historia de la Construcción. Santiago de Compostela.

Lluis, J.; Fortuny G.; Costa A., Sola-Morales P., (2013). Gothic Construction and the Traça of a Heptagonal Apse: The Problem of the Heptagon. Nexus Network Journal, 15, Issue 2, 325-348.

Lourenço, P.B., (2001). Analysis of historical constructions: from thrust-lines to advanced simulations. In Lourenço P.B., Roca P. (Eds.), Historical Constructions (98), Guimaraes.

Macareno, L.M., Angulo, C., López, D., Agirrebeitia, J., (2007). Analysis and characterization of the behavior of a variable geometry structure. Proceedings of the Institution of Mechanical Engineers. Part C: Journal of Mechanical Engineering science, 221 (11), 1427-1434.

Martínez, S., Ortiz, J., Gil, Mạ., Rego, Mạ., (2013). Recording complex structures using Close Range Photogrammetry: the Cathedral of Santiago de Compostela. The Photogrammetric Record, 28 (144), 375-395. 
Morán Proaño, M., Álvarez Rodríguez, O., (2012). Investigación de las vibraciones por tráfico en las construcciones patrimoniales de adobe. Revista de la Construcción, 11 (2), 39-53.

Moropoulou, A., Labropoulos, K.C., Delegou, E.T., Karaglou, M., Bakolas, A., (2013). Construction and Building Materials, $48,1222-1239$

Núñez, M.A., Buill, F., Regot, J., de Mesa, A, (2012) Levantamiento arquitectónico de la Puerta de Antioquía (Alepo). Informes de la Construcción, Vol. 64 (528), 487-496.

Ordoñez, C., Martínez, J., Arias, P., Armesto, J., (2010). Measuring building façades with low-cost close-range photogrammetry system. Automation in Construction, 19 (6), 742-749.

Riveiro, B., Caamaño, J.C., Arias, P., Sanz, E., (2010). Photogrammetric 3D modelling and mechanical analysis of masonry arches: An approach based don discontinuous model voussoirs. Automation in Construction, 20(4), 380-388.

Riveiro, B., Solla, M., de Arteaga, I., Arias, P., Morer, P., (2013). A novel approach to evaluate masonry arch stability on the basis of limit analysis theory and non-destructive geometric characterization. Automation in construction $31,140-148$.

Roca, P., Cervera, M., Gariup, G., Pela, L., (2010). Structural analysis of masonry historical constructions. Classical and Advanced Approaches. Archives of Computational Methods in Engineering, 17 (3), 299-325.

Rosin, P.L., (1996). Assessing error of fit functions for ellipses, Graphical Models and Image Processing, 58(5), 494-502.

Rosin, P.L., Pitteway, (2001). The ellipse and the five-centred arch, The Mathematical Gazette, 85(502), 13-25.

Sharaf Al-kheder, Yahya Al-shawabkeh, Norbert Haala (2009). Developing a documentation system for desert palaces in Jordan using 3D laser scanning and digital photogrammetry. Journal of Archaeological Science, $36(2), 537-546$.

Schueremans, L., Van Genechten B., (2009). The use of 3D-laser scanning in assessing the safety of masonry vaults - a case study on the church of Saint Jacobs. Optics and Lasers in Engineering 47 (3-4) 329-355.

Ungewitter, G., (1890-1892). Lehrbuch der Gotischen Konstruktionen. 2 Vol. Leipzig: T.O. Weigel Nachfolger.

Valentini, J., (1990). II duomo de Milano. Una disputa medievales sul modelo del Tempio. Milano: Nuove Edizioni Duomo.

Viollet-le-Duc, E. E., (1854-1868). Dictionnaire raisonné de I'architecture française du Xle au XVle siècle. Paris: B. Bance (A. Morel), 10(4), 61-121.

Viollet-le-Duc, E. E., (1996). The construction of Middle Ages. The paper $<<$ Construcction $>>$ from the Dictionnaire raisonné de l'architecture française du XIe au XVIe siècle. Madrid: CEHOPU.

Yarza, (1982). Arte Medieval II. Románico y Gótico. Barcelona: Gustavo Gili.
Yastikli, N., (2007). Documentation of cultural heritage using digital photogrammetry and laser scanning. Journal of Cultural Heritage, 8(4), 423-427.

Yilmaz, H. M., Yakar, M., Yildiz, F., (2008). Documentation of historical caravansaries by digital close range photogrammetry. Automation in Construction, 17 (4), 489-498.

Willis, R., (1842). On the construction of the vaults of the Middle Ages. Transactions of the Royal Instituto of Britísh Architects Vol1, part 2. London: Longman. 